\title{
Bacteriological Quality of Raw Pork Sold in Retailed Butcher Shops of Aizawl and Imphal
}

\author{
M. Das ${ }^{1 *}$, E. Motina ${ }^{1}$, D. Deka ${ }^{1}$, N.S. Singh ${ }^{2}$, T.K. Dutta ${ }^{3}$, \\ P. Roychoudhury ${ }^{3}$ and S. Chakraborty ${ }^{3}$ \\ ${ }^{1}$ Department of Veterinary Public Health and Epidemiology, ${ }^{2}$ Department of Animal Breeding \\ and Genetics, ${ }^{3}$ Department of Veterinary Microbiology, College of Veterinary \\ Sciences \& AH, CAU, Selesih Aizawl, Mizoram, India \\ *Corresponding author
}

\section{A B S T R A C T}

Keywords

Raw pork,

Bacteriological, TVC,

CC, FSC, Aizawl,

Imphal

Article Info

Accepted:

10 April 2018

Available Online:

10 May 2018
A total of 200 raw pork samples (Aizawl=100, Imphal=100) were subjected for Total Viable Count (TVC), Coliform Count (CC) and Faecal Streptococcal Count (FSC). The overall mean TVC was recorded as $5.9985 \pm 0.0254 \log _{10} \mathrm{cfu} / \mathrm{g}$. However, the mean TVC were reported as $6.0577 \pm 0.0406$ and $5.9393 \pm 0.0295$ $\log _{10}$ cfu/g from Aizawl and Imphal, respectively with significant variation between Aizawl and Imphal at $10^{-4}$ dilution $(\mathrm{P}<0.05)$ and at $10^{-5}$ dilution $(\mathrm{P}<0.01)$. All the pork samples from Aizawl and $98.00 \%$ samples from Imphal showed positive for coliform organisms. The overall mean CC was recorded as $5.2727 \pm$ $0.0707 \log _{10} \mathrm{cfu} / \mathrm{g}$ with the mean values of $5.3828 \pm 0.0945 \log _{10} \mathrm{cfu} / \mathrm{g}$ from Aizawl and $5.1627 \pm 0.1045 \log _{10} \mathrm{cfu} / \mathrm{g}$ from Imphal. The overall mean FSC was recorded $2.7794 \pm 0.1219 \log _{10} \mathrm{cfu} / \mathrm{g}$ without any significant variation between Aizawl and Imphal.

\section{Introduction}

Food is the major need for the survivability of the all living organisms. Thus it acts as a major route of transmission for all types of contamination by chemical and microbiological contaminants. Bacterial contamination of food is the most common cause of food-borne illness resulting $70 \%$ of deaths associated with food-borne diseases (Adak et al., 2002; Lynch et al., 2006). Meat is considered as one of the most important food items for human consumption from the ancient time and a major proportion of the worldwide population chiefly relies on meat as a potent source of good quality protein (Bradeeba and Sivakumaar, 2013). All over the world, pork shares about $38 \%$ of meat production (Jeffries 2012). Pork, being the most important meat in North-Eastern Region of India, the pig population shares $38 \%$ of total pig population of India with contribution of $18.77 \%$ of India's total pork production and in hike with every passing year. 
Of the total meat production of NER, pork meat contributes 36\% (85.02 thousand tones out of 235.29 thousand tonnes) in 2012-13 (Basic Animal Husbandry Statistics 2013, AHDF, GoI).

Manipur and Mizoram are two states of NorthEastern Hilly Region with the pig population of 278 thousands and 245 thousands in Manipur and Mizoram, respectively $\left(19^{\text {th }}\right.$ Livestock Census, 2012) and pork shares 27\% and $57 \%$ of total meat production in Manipur and Mizoram.

Fresh raw meat contains high level of nutrients with water activity of 0.98-0.99, and a $\mathrm{pH}$ ranging from 5.5 to 5.6; which favour the growth of microorganism (Acuff, 2005).

Under the unhealthy and unhygienic practices in meat production chain, meat is subjected to microbial contamination (Kumar et al., 2001) that comes in contact with meat during the production, processing, transportation and distribution and causes health problems of infection and intoxications (Ramasastry et al., 1999; Dhanze et al., 2012) and spoilage.

Meat is frequently contaminated with high level of Klebsiella pneumoniae, Enterobacter sp., Pseudomonas aeruginosa, Escherichia coli, Salmonella spp., Serratia marcescense and Protius vulgaris, Staphylococcus aureus and Bacillus sp. (Ukut et al., 2010; Ateba and Setona 2011).

Keeping this point in view, the present study was conducted on bacteriological quality of raw pork sold in retailed butcher shops of Aizawl and Imphal, the capital cities of Mizoram and Manipur, respectively. Materials and Methods

A total of 200 number of raw pork samples (100 gram each) were collected aseptically from unorganized local markets of Aizawl and
Imphal during the period of July 2016 to December 2016 and were processed immediately upon arrival in the laboratory for bacteriological quality. The TVC, CC and FSC were determined according to the procedure recommended by American Public Health Association (1976) and Quinn et al., (1994). Twenty five grams of raw pork sample was weighed and placed into $225 \mathrm{ml}$ one percent peptone water and placed in a stomacher for two minutes. Subsequently 10fold dilutions of meat samples were made up to $10^{-6}$ and $0.1 \mathrm{ml}$ from appropriate dilution was transferred to sterilized plate using micropipette. The inoculated samples were spread on to the entire surface of the agar plates, Nutrient agar, MacConkey agar and Slantz \& Bartley agar for TVC, CC and FSC, respectively with a sterile glass spreader and the plates were incubated at $37^{\circ} \mathrm{C}$ to for $24-48$ hours. Following incubation, plates exhibiting 30 to 300 bacterial colonies were counted. The average number of colonies in a particular dilution was multiplied by the dilution factor to obtain the TVC and the results of the TVC were expressed as mean log colony forming unit (cfu) per gram. Statistical analysis was done by one way ANOVA (Snedecor and Cochran, 1994).

\section{Results and Discussion}

All the enumerated values of TVC, CC and FSC were expressed in terms of $\log _{10}$.

\section{Total Viable Count (TVC) in raw pork}

The overall TVC of raw pork samples from Aizawl and Imphal ranged between 3.35 and $6.46 \log _{10} \mathrm{cfu} / \mathrm{g}$ with a mean value of $5.9985 \pm$ $0.0254 \log _{10} \mathrm{cfu} / \mathrm{g}$. However, the TVC of raw pork from Aizawl and Imphal ranged from 3.35 to 6.46 and 4.62 to 6.40 with a mean value of $6.0577 \pm 0.0406$ and $5.9393 \pm 0.0295$ $\log _{10} \mathrm{cfu} / \mathrm{g}$, respectively (Table 1; Fig. 1). 
The overall mean TVC of pork samples varied significantly $(\mathrm{P}<0.05)$ between Aizawl and Imphal with a significant difference in TVC at $10^{-4}(\mathrm{P}<0.01)$ and $10^{-5}(\mathrm{P}<0.05)$ dilutions. However, no significant difference was observed in $10^{-3}$ dilution between Aizawl and Imphal.

For detection of bacterial quality of raw meat, total viable counts (TVC) has been widely accepted measure of the general degree of microbial contamination and hygienic conditions of processing plants (Cohen et al., 2007). It estimates the total numbers of viable micro-organism present in a set volume of meat sample and the results is considered as a level of magnitude against the prescribed standard. Inthvang et al., (2006) reported the range of APC of fresh pork ranging from 4.44$5.3 \log _{10} \mathrm{cfu} / \mathrm{g}$ from Vientane, which was less than the ranges of TVC of pork found in Aizawl and Imphal. However, Lambey et al., (2016) reported higher mean value of TVC (7.78 $\log _{10} \mathrm{cfu} / \mathrm{g}$ ) from Mathura region of India and the higher level of microbial contamination of pork in Mathura might be due to complex city life than North Eastern Hill states. In numbers of studies made by Bradeeba and Sivakumar (2013) and Singh et al., (2014) also showed the high mean value of TVC $5.89 \pm 0.17$ and $6.86 \pm 0.02\left(\log _{10} \mathrm{cfu} / \mathrm{g}\right)$, respectively in retailed pork samples from Chidambaram, TN and Agra region. In and around Anitsha, Nigeria, Nnachi and Ukaegbu (2014) showed much higher level of bacterial contamination of raw pork with a mean Total Aerobic Count of $9.84 \pm 0.14\left(\log _{10} \mathrm{cfu} / \mathrm{g}\right)$. Anachinaba et al., (2015) showed the bacterial quality as microbial load of $5.13 \mathrm{log} \mathrm{cfu} / \mathrm{g}$ of fresh pork and $5.67 \log _{10} \mathrm{cfu} / \mathrm{g}$ of smoked pork, in Ghana which was lesser than the findings in the present study.

\section{Coliform Count (CC) and Faecal Streptococcal count in raw pork}

Other than TVC, Coliform Count and Faecal streptococcal count (FSC) are the two major parameters for determination of faecal contamination of raw meat. Faecal materials are major sources of meat contamination via direct deposition and indirect contact through contaminated equipments, tools, vehicles and even workers (Borch and Arinder, 2002). Coli form Count, especially Escherichia coli is the indicator of faecal contamination; whereas FSC is the unique determinant of recent contamination. High load of E. coli in raw meat from abattoirs and retail shops may contribute in spoilage and food-borne illnesses (Ahmed et al., 2013) (Fig. 2).

Fig.1 Graphical representation of Total Viable Count (TVC) of raw pork in Aizawl and Imphal

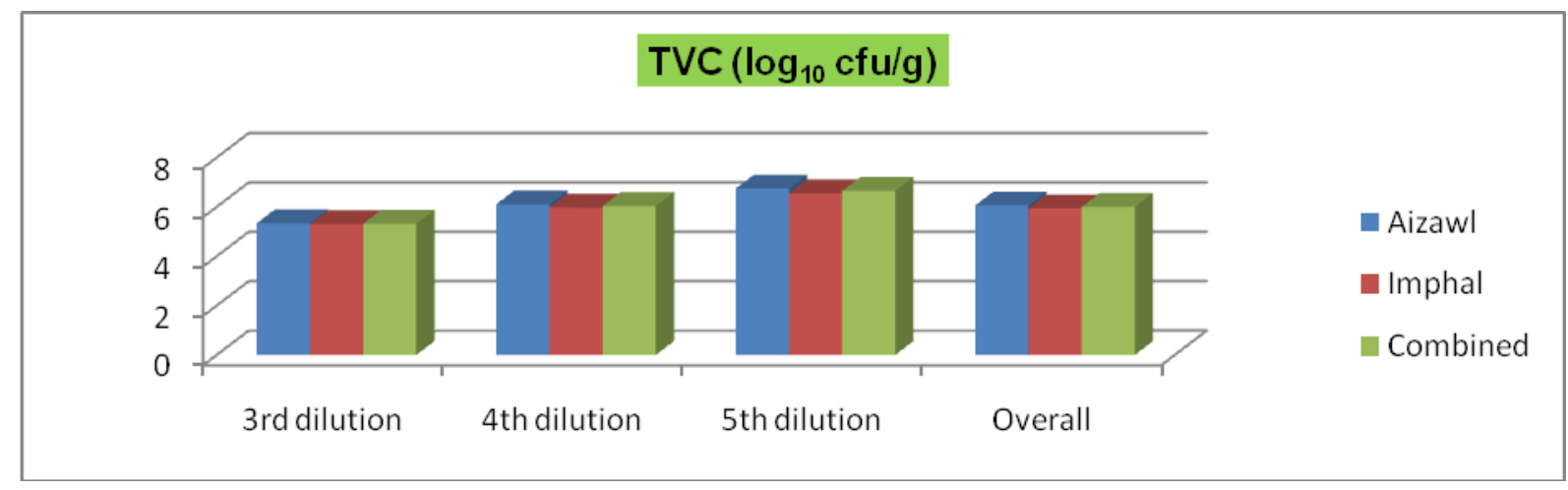


Fig.2 Graphical representation of Coliform Count (CC) of raw pork in Aizawl and Imphal

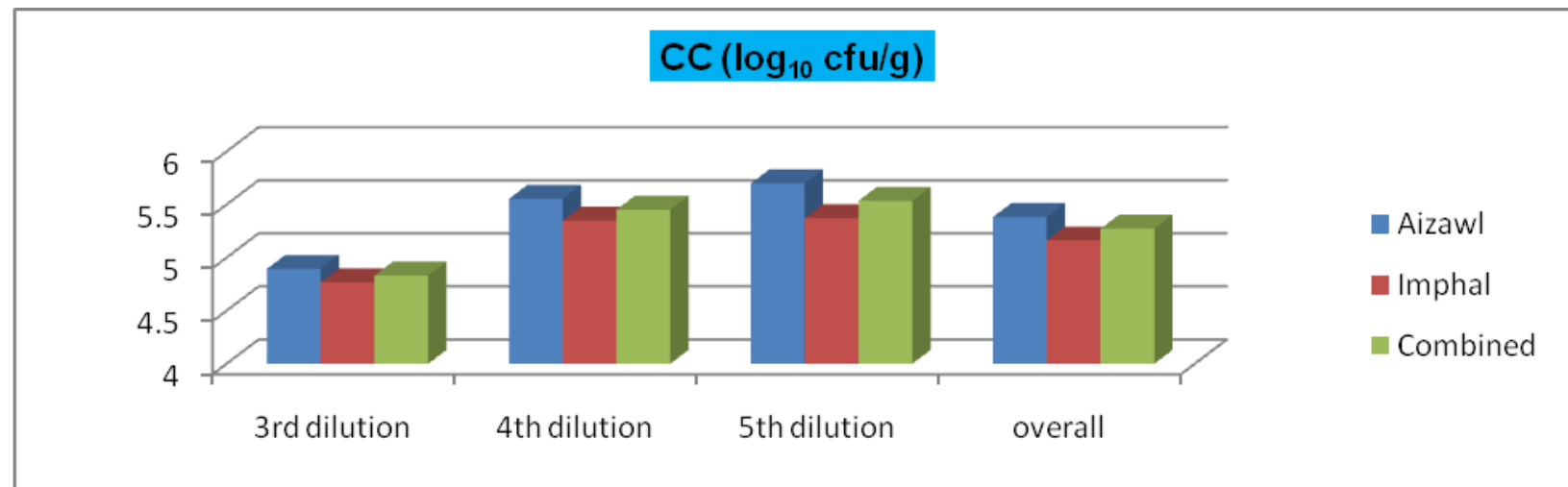

Fig.3 Graphical representation of Faecal Streptococcal Count (FSC) of raw pork in Aizawl and Imphal

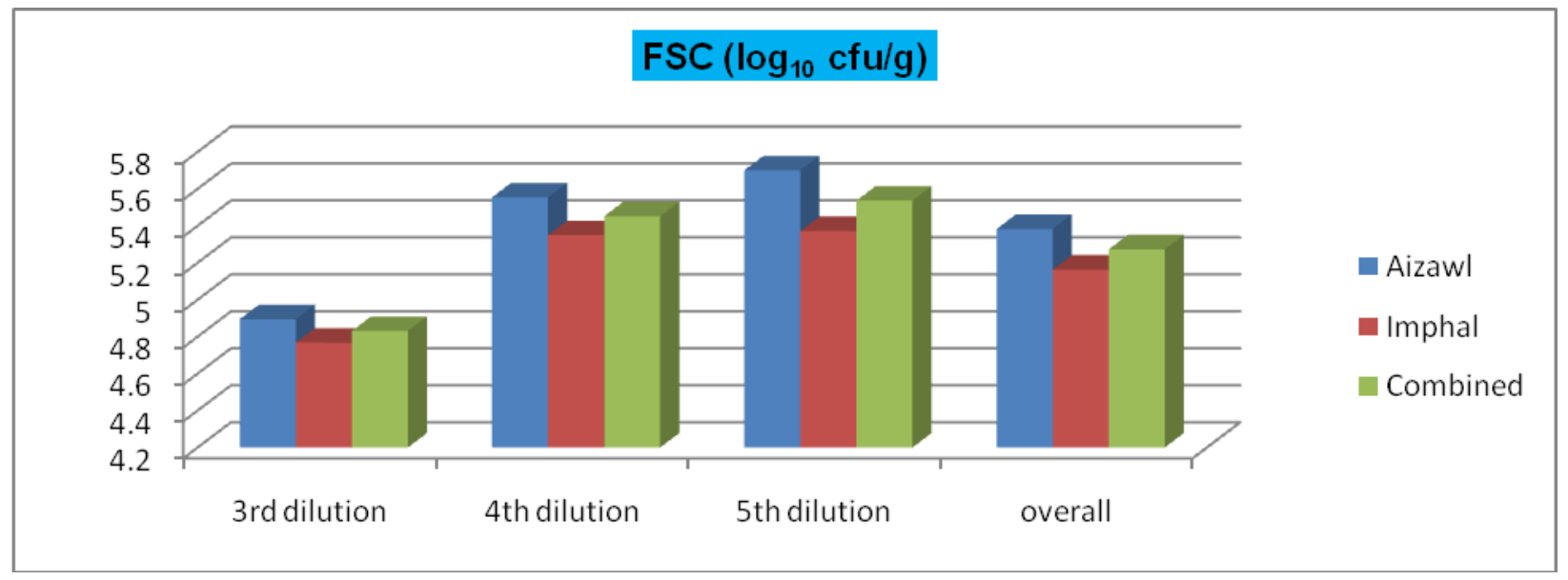

Table.1 Mean TVC of raw pork samples from Aizawl and Imphal in different dilutions

\begin{tabular}{|c|c|c|c|c|}
\hline Parameter & Aizawl (n=100) & Imphal $(n=100)$ & Combined $(\mathrm{n}=200)$ & F-value \\
\hline \multicolumn{5}{|l|}{ TVC } \\
\hline $10^{-3}$ & $\begin{array}{l}5.3336 \pm 0.0267 \\
(4.08-5.59)\end{array}$ & $\begin{array}{l}5.2994 \pm 0.0222 \\
(4.08-5.56)\end{array}$ & $\begin{array}{l}5.3165 \pm 0.0173 \\
(4.08-5.59)\end{array}$ & $0.973^{\mathrm{NS}}$ \\
\hline $10^{-4}$ & $\begin{array}{l}6.1016 \pm 0.0350^{a} \\
(4.70-6.48)\end{array}$ & $\begin{array}{l}5.9706 \pm 0.0284^{b} \\
(4.78-6.51)\end{array}$ & $\begin{array}{l}6.0361 \pm 0.0229 \\
(4.70-6.51)\end{array}$ & $8.439 * *$ \\
\hline $10^{-5}$ & $\begin{array}{l}6.7379 \pm 0.0821^{a} \\
(0.00-7.35)\end{array}$ & $\begin{array}{l}6.5479 \pm 0.0447^{b} \\
(5.00-7.26)\end{array}$ & $\begin{array}{l}6.6429 \pm 0.0471 \\
(0.00-7.35)\end{array}$ & $4.130 *$ \\
\hline Overall & $\begin{array}{l}6.0577 \pm 0.0406^{a} \\
(3.35-6.46)\end{array}$ & $\begin{array}{l}5.9393 \pm 0.0295^{b} \\
(4.62-6.40)\end{array}$ & $\begin{array}{l}5.9985 \pm 0.0254 \\
(3.35-6.46)\end{array}$ & $5.553 *$ \\
\hline
\end{tabular}

NS- Non-significant at $\mathrm{P}<0.05$; * Significant at $\mathrm{P}<0.05$; ** Significant at $\mathrm{P}<0.01$; Figures within the parentheses indicates the range values. 
Table.2 The details of CC of raw pork in different dilutions from Aizawl and Imphal

\begin{tabular}{|c|c|c|c|c|}
\hline Parameter & Aizawl $(n=100)$ & Imphal (n=100) & combined $(\mathrm{n}=200)$ & F-value \\
\hline \multicolumn{5}{|l|}{$\mathrm{CC}$} \\
\hline $10^{-3}$ & $\begin{array}{l}4.8940 \pm 0.0427 \\
(3.00-5.48)\end{array}$ & $\begin{array}{l}4.7673 \pm 0.0769 \\
(0.00-5.40)\end{array}$ & $\begin{array}{l}4.8307 \pm 0.0442 \\
(0.00-5.48)\end{array}$ & $2.073^{\mathrm{NS}}$ \\
\hline $10^{-4}$ & $\begin{array}{l}5.5539 \pm 0.0785 \\
(0.00-6.32)\end{array}$ & $\begin{array}{l}5.3492 \pm 0.0888 \\
(0.00-6.23)\end{array}$ & $\begin{array}{l}5.4516 \pm 0.0596 \\
(0.00-6.32)\end{array}$ & $2.981^{\mathrm{NS}}$ \\
\hline $10^{-5}$ & $\begin{array}{l}5.7005 \pm 0.1988 \\
(0.00-7.28)\end{array}$ & $\begin{array}{l}5.3715 \pm 0.1757 \\
(0.00-6.90)\end{array}$ & $\begin{array}{l}5.5360 \pm 0.1328 \\
(0.00-7.28)\end{array}$ & $1.538^{\mathrm{NS}}$ \\
\hline Overall & $\begin{array}{l}5.3828 \pm 0.0945 \\
(2.33-6.28)\end{array}$ & $\begin{array}{l}5.1627 \pm 0.1045 \\
(0.00-6.09)\end{array}$ & $\begin{array}{l}5.2727 \pm 0.0707 \\
(0.00-6.28)\end{array}$ & $2.444^{\mathrm{NS}}$ \\
\hline
\end{tabular}

NS- Non-significant at $\mathrm{P}<0.05$; * Significant at $\mathrm{P}<0.05$; ** Significant at $\mathrm{P}<0.01$; Figures within the parentheses indicates the range values.

Table.3 The FSC in raw pork samples at different dilutions from Aizawl and Imphal

\begin{tabular}{|c|c|c|c|c|}
\hline Parameter & Aizawl $(n=100)$ & Imphal $(n=100)$ & Combined(n=200) & F-value \\
\hline \multicolumn{5}{|l|}{ FSC } \\
\hline $10^{-3}$ & $\begin{array}{l}3.1317 \pm 0.1874 \\
(0.00-5.32)\end{array}$ & $\begin{array}{l}3.8630 \pm 0.0779 \\
(0.00-4.92)\end{array}$ & $\begin{array}{l}3.4973 \pm 0.1045 \\
(0.00-5.32)\end{array}$ & $12.989 * *$ \\
\hline $10^{-4}$ & $\begin{array}{l}2.8820 \pm 0.2357 \\
(0.00-6.05)\end{array}$ & $\begin{array}{l}3.3858 \pm 0.1994 \\
(0.00-5.69)\end{array}$ & $\begin{array}{l}3.1339 \pm 0.1550 \\
(0.00-6.05)\end{array}$ & $2.663^{\mathrm{NS}}$ \\
\hline $10^{-5}$ & $\begin{array}{l}1.8698 \pm 0.2638 \\
(0.00-6.79)\end{array}$ & $\begin{array}{l}1.5440 \pm 0.2375 \\
(0.00-6.04)\end{array}$ & $\begin{array}{l}1.7069 \pm 0.1774 \\
(0.00-6.79)\end{array}$ & $0.843^{\mathrm{NS}}$ \\
\hline Overall & $\begin{array}{l}2.6278 \pm 0.1982 \\
(0.00-5.90)\end{array}$ & $\begin{array}{l}2.9309 \pm 0.1416 \\
(0.00-5.52)\end{array}$ & $\begin{array}{l}2.7794 \pm 0.1219 \\
(0.00-5.90)\end{array}$ & $1.549^{\mathrm{NS}}$ \\
\hline
\end{tabular}

NS- Non-significant at $\mathrm{P}<0.05 ; *$ Significant at $\mathrm{P}<0.05$; ** Significant at $\mathrm{P}<0.01$; Figures within the parentheses indicates the range values.

\section{Coli form count (CC)}

In the present study, all the 100 raw pork samples from Aizawl and 98 samples from Imphal were found to be positive for coliforms. The overall mean CC from Aizawl and Imphal ranged from 0 to 6.28 with a mean value of $5.2727 \pm 0.0707 \log _{10} \mathrm{cfu} / \mathrm{g}$. The mean value of $\mathrm{CC}$ of raw pork were $5.3828 \pm 0.0945 \log _{10} \mathrm{cfu} / \mathrm{g}$ and $5.1627 \pm .1045$ $\log _{10} \mathrm{cfu} / \mathrm{g}$ with a range from 2.33 to 6.28 and 0 to $6.09 \log _{10} \mathrm{cfu} / \mathrm{g}$ from Aizawl and Imphal, respectively without any significant variation between Aizawl and Imphal (Table 2). The mean value of $\mathrm{CC}$ of raw pork between Aizawl and Imphal in different dilutions showed no significant difference. In a study, Lambey et al., (2016) and Singh et al., (2014) reported the Coliform count of 4.29 and 3.40 $\pm 0.10\left(\log _{10} \mathrm{cfu} / \mathrm{g}\right)$, respectively for pork which was lower than the present study. Nnachi and Ukaegbu (2014) showed a very high Total Coliform Count in raw pork, $9.65 \pm 0.10 \quad\left(\log _{10} \quad \mathrm{cfu} / \mathrm{g}\right)$. The coliforms organisms are considered as primary and most reliable indicator for water quality. So, the presence of coliform in pork denotes the poor quality of water used in dressing and unhygienic environment for selling of pork. The presence of coliform organisms was high in raw pork in Aizawl and Imphal indicating poor hygienic condition of market pork and 
water borne contamination in both the places. Bradeeba and Sivakumar (2013) reported that mean Coliform Count increased with the advancement of time from $2.00 \pm 0.06$ to 5.56 $\pm 0.016\left(\log _{10} \mathrm{cfu} / \mathrm{g}\right)$.

\section{Faecal streptococcal count}

The present study indicated that 80 and 97 numbers of raw pork samples from Aizawl and Imphal were positive for the Faecal Streptococcal organisms, respectively. The FSC were found in a range from 0 to 5.90 $\log _{10} \mathrm{cfu} / \mathrm{g}$ in Aizawl and Imphal with overall mean value of $2.7794 \pm 0.1219 \log _{10} \mathrm{cfu} / \mathrm{g}$. The mean value of FSC in raw pork samples from Aizawl was found to be $2.6278 \pm$ 0.1982 with a range from 0 to $5.90 \log _{10} \mathrm{cfu} / \mathrm{g}$ whereas the mean value of FSC of raw pork sample from Imphal was recorded as 2.9309. $\pm 0.1416 \log _{10} \mathrm{cfu} / \mathrm{g}$ with a range from 0 to $5.52 \log _{10} \mathrm{cfu} / \mathrm{g}$ (Table 3) and there was no significant difference between Aizawl and Imphal at any dilution. Detection of Faecal Streptococci indicated the recent contamination of water by human excreta or faecal materials (Fig. 3).

A great diversity of microbes inhabits in fresh meat generally, but different types may become dominant depending on $\mathrm{pH}$, composition, texture, and storage temperature and transportation means of raw meat (AduGyamfi et al., 2012).

\section{References}

$19^{\text {th }}$ Livestock Census. 2012. http:// dahd.nic.in/sites/default/files/Livestock $\% 20 \% 205$.pdf.

Acuff, G.R. 2005. Chemical decontamination strategies for meat. In: Improving the safety of fresh meat, FL: CRC Press, Boca Raton, pp. 350-363.

Adak, G.K., Long, S.M. and O'Brien, S.J. 2002. Trends in indigenous foodborne disease and deaths, England and Wales, 1992 to 2000. Gut. 51(6): 832-841.

Adu-Gyamfi, A., Torgby, T.W. and Appiah, V. 2012. Microbiological quality of chicken sold in Accra and determination of D10-Value of E. coli. Food Nutr. Sci. 3(05): 693-698.

Ahmed, M.U.D., Sarwar, A., Najeeb, M.I., Nawaz, M., Anjum, A.A., Ali, M.A. and Mansur, N. 2013. Assessment of microbial load of raw meat at abattoirs and retail outlets. J. Anim. Plant Sci. 23: 745-748.

American Public Health Association (APHA) (1976) Compendium of methods for the microbiological examination of foods. Speck, ML ed. 1015, Eighteen street, New York, Washington D.C. 20036.

Anachinaba, I.A., Adzitey, F. and Tere, G.A. 2015. Assessment of Microbial quality of Locally Produced Meat (Beef and Pork) in Bolgatanga Municipal of Ghana. Int. J. Food Saf. 17: 1-5.

Ateba, C.N. and Setona, T. 2011. Isolation of enteric bacterial pathogens from raw mince meat in Mafikeng, North-West Province, South Africa. Life Sci. J. 8: S2.

Basic Animal husbandry Statistics, AHDF, Govt. of India. 2013.

Borch, E. and Arinder, P. 2002. Bacteriological safety issues in red meat and ready-to-eat meat product, as well as control measures. Meat Sci. 62(3): 381-390.

Bradeeba, K. and Sivakumaar, P.K. 2013. Assessment of microbial quality of beef, mutton and pork and its environment in retail shops in Chidambaram, Tamil Nadu. Int J Plant Anim. Environ. 3: 9197.

Cohen, N., Ennaji, H., Bouchrif, B., Hassar, M. and Karib, H. 2007. Comparative study of microbiological quality of raw poultry meat at various seasons and for different slaughtering process in 
Casablanca (Morocco). J Appl. Poul. Res. 16(4): 502-508.

Dhanze, H., Khurana, S.K. and Mane, B.G. 2012. Microbiological quality of eggs, chicken and chevon sold in market of Palampur, H.P. J. Vet. Pub. Hlth. 10(1): 53-55.

Inthavong, P., Srikitjakarn, L., Kyule, M., Zessin, K.H., Baumann, M., Douangngeun, B. and Fries, R. 2006. A cross-sectional study was conducted to determine microbial contamination of pig carcasses at a slaughterhouse in Vientane, capital of Lao People Democratic Republic (Leo PDR Correspondence: DrLertrakSrikitjakarn, Faculty of Veterinary Medicine, Chiang Mai University, Chiang Mai, 50100, Thailand). 37: 1237-1241.

Jeffries, W. 2012. Mother Earth News-What Good Is a Pig, Homesteading and livestock. Available from: http://www. motherearthnews.com/homesteadingand livestock/what-good-is-a-pig-cutsof-pork-nose-to-tail. Accessed on05-052012.

Kumar, H.S., Ottu, S. and Karunasagar, I. 2001. Detection of Shiga toxigenic Escherichia coli in fresh sea food and meat marketed in Mangalore, India by PCR. Lett. Appl. Microbiol. 33(5): 334338.

Lambey, H.S., Verma, A.K. and Jain, U. 2016. Bacteriological quality of chevon and pork in Mathura city U.P (India). J. Vet. Pub. Hlth. 7(2): 141-143.
Lynch, M., Painter, J., Woodruff, R. and Braden, C. 2006. Surveillance for foodborne-disease outbreaks-United States, 1998-2002. US Department of Health and Human Services, Centres for Disease control and Prevention (CDC), 2006. 55: 1-34.

Nnachi, A.U. and Ukaegbu, C.O. 2014. Microbial quality of raw meat sold in Onitsha, Anambra State, Nigeria. Int. J. Sci. Res. 3: 214-218.

Quinn, P.J., Carter, M.E., Markey, B.K. and Carter, G.R. 1994. In: Clinical Veterinary Microbiology. Wolf Publishing. London, UK: pp. 21-66.

Ramsastry, P., Rao, R.M. and Mrunalini, M. 1999. Bacterial profile of frozen meat. Ind Vet J. 76: 409-411.

Singh, V.K., Jain, U., Yadav, J.K. and Bist, B. 2014. Assessment of bacterial quality of raw meat samples (carabeef, chevon, pork and poultry) from retail meat outlets and local slaughter houses of Agra region, India. J. Foodborne Zoonotic. Dis. 2(1): 15-18.

Snedecor, G.W. and Cochran, W.G. 1994. Statistical methods, $8^{\text {th }}$ edn.Lowa State University Press, USA.

Ukut, I.O.E., Okonto, I.O., Ikpoh, I.S., Nkang, A.O., Babalola, T.A., Mejeha, O.K. and Fajobi, E.A. 2010. Assessment of bacteriological quality of fresh meat sold in calabar metropolis, Nigeria. Electron. J. Environ. Agric. Food Chem. 9(1): 89-100.

\section{How to cite this article:}

Das, M., E. Motina, D. Deka, N.S. Singh, T.K. Dutta, P. Roychoudhury and Chakraborty, S. 2018. Bacteriological Quality of Raw Pork Sold in Retailed Butcher Shops of Aizawl and Imphal. Int.J.Curr.Microbiol.App.Sci. 7(05): 1189-1195. doi: https://doi.org/10.20546/ijcmas.2018.705.145 